\title{
Expression of membrane antigens in myotonic dystrophy
}

\author{
FRANK S WALSH, STEPHEN E MOORE, JOHN G DICKSON \\ From the Institute of Neurology, Queen Square, London, UK
}

SUMMARY Muscle biopsies from a series of myotonic dystrophy patients were analysed for expression of the nerve regulated gene products neural cell adhesion molecule (N-CAM) and $5 \cdot 1 \mathrm{H} 11$. All eight biopsy specimens tested strongly expressed $\mathrm{N}-\mathrm{CAM}$ and $5 \cdot 1 \mathrm{H} 11$ as assessed by indirect immunofluorescence analysis. These results can be compared with those of Renaud et al (Nature, 1986;319:678) that show apamin binding to be a good marker of myotonic dystrophy muscle membranes. We suggest that in myotonic dystrophy a number of nerve regulated membrane markers are precociously expressed by innervated myofibres and that these are likely to be secondary manifestations resulting from an unidentified primary defect.

Myotonic dystrophy is an autosomal dominant disease affecting muscle and a variety of other organs. ${ }^{1}$ The defective gene has recently been assigned to the short arm of chromosome $19^{2} 3$ but has not yet been isolated. Experimental studies on the cell membrane of muscle and non-muscle cells from myotonic dystrophy patients has led to the suggestion that the primary gene defect is expressed at the cell membrane. ${ }^{4}$ These data are, however, also compatible with a defect at another site leading secondarily to cell membrane changes. Renaud et $a l^{5}$ have recently found that ${ }^{125} \mathrm{I}$-apamin binding sites are present in myotonic dystrophy muscle and may be a good marker for the membranes of muscle cells in myotonic dystrophy. This claim was based on the observation that apamin receptors were present in myotonic dystrophy muscle tissue but not in samples from control patients or patients with anterior horn disorders. If any cell membrane molecule is to be considered to be a good marker of a neuromuscular disease it should fulfil a number of basic criteria. These should include an element of specificity in its pattern of expression such

Address for reprint requests: Dr F S Walsh, Department of Neurochemistry, Institute of Neurology, Queen Square, London WCIN 3BG. UK

Received 6 February 1987 and in revised form 2 June. Accepted 8 June 1987. that other membrane markers with similar modes of regulation are not also expressed and there should be disease specificity such that neuromuscular disease of unrelated pathology should not express the marker. We report here that two human muscle mem brane components whose regulation appears to be coordinate with apamin binding, ${ }^{6-8}$ namely neura? cell adhesion molecule $(\mathrm{N}-\mathrm{CAM})^{9-13}$ and $5 \cdot 1 \mathrm{H} 11$ antigen ${ }^{1415}$ have a similar profile of reactivity to apamin binding on myotonic dystrophy and other muscle samples. We therefore suggest that apamin binding may not be a good marker for myotonic dystrophy but instead may define simply a set of gene products that are coordinately regulated pathologically but with a lack of specificity.

\section{Methods}

The eight myotonic dystrophy biopsy specimens used in the present study were obtained from patients (four male and four female; age range $23-50$ years, mean $=38$ ) presenting at the National Hospital, London, and were diagnosed by Dr J Morgan-Hughes. Indirect immunofluorescence analysis and haematoxylin and eosin (H\&E) staining was carried out on these specimens as described previously. ${ }^{15}$ The antibodies used were either rabbit anti-D2-CAM that reacts with $\mathrm{N}-\mathrm{CAM}^{16}$ (generously donated by Dr E Bock, Protein Laboratory, University of Copenhagen), or mouse monoclonal antibody (McAb) $5 \cdot 1 \mathrm{H} 11 .^{1415}$ For fibre type analysis serial sections were stained with McAb 29.1D12 which 
reacts with adult fast myosin heavy chain. ${ }^{17}$ In all cases the staining found with the antibodies was specific as omission of the first antibody or substitution of an antibody that did not react with muscle cells led to a complete loss of specific staining.

\section{Results}

A series of myotonic dystrophy biopsy specimens were stained with $\mathrm{N}-\mathrm{CAM}$ and $5 \cdot 1 \mathrm{H} 11$ antibodies. The figure shows a typical example of a myotonic dystrophy muscle biopsy specimen double stained with these two reagents and serial sections stained by antifast myosin or H\&E. The biopsy shows features characteristic of myotonic dystrophy such as type 1 fibre atrophy, type 2 fibre hypertrophy and a large number of internal nuclei. ${ }^{1}$ The type 2 fibres are strongly positive for both $\mathrm{N}-\mathrm{CAM}$ and $5 \cdot 1 \mathrm{H} 11$. This was a reproducible feature of all specimens tested but the significance of this observation is not clear at present. Staining is associated with both the cell membrane and cytoplasm of myofibres, as has been found in other pathological material with these two antibodies. ${ }^{1518}$ The significance of the cytoplasmic staining is not yet known, but by analogy to animal studies
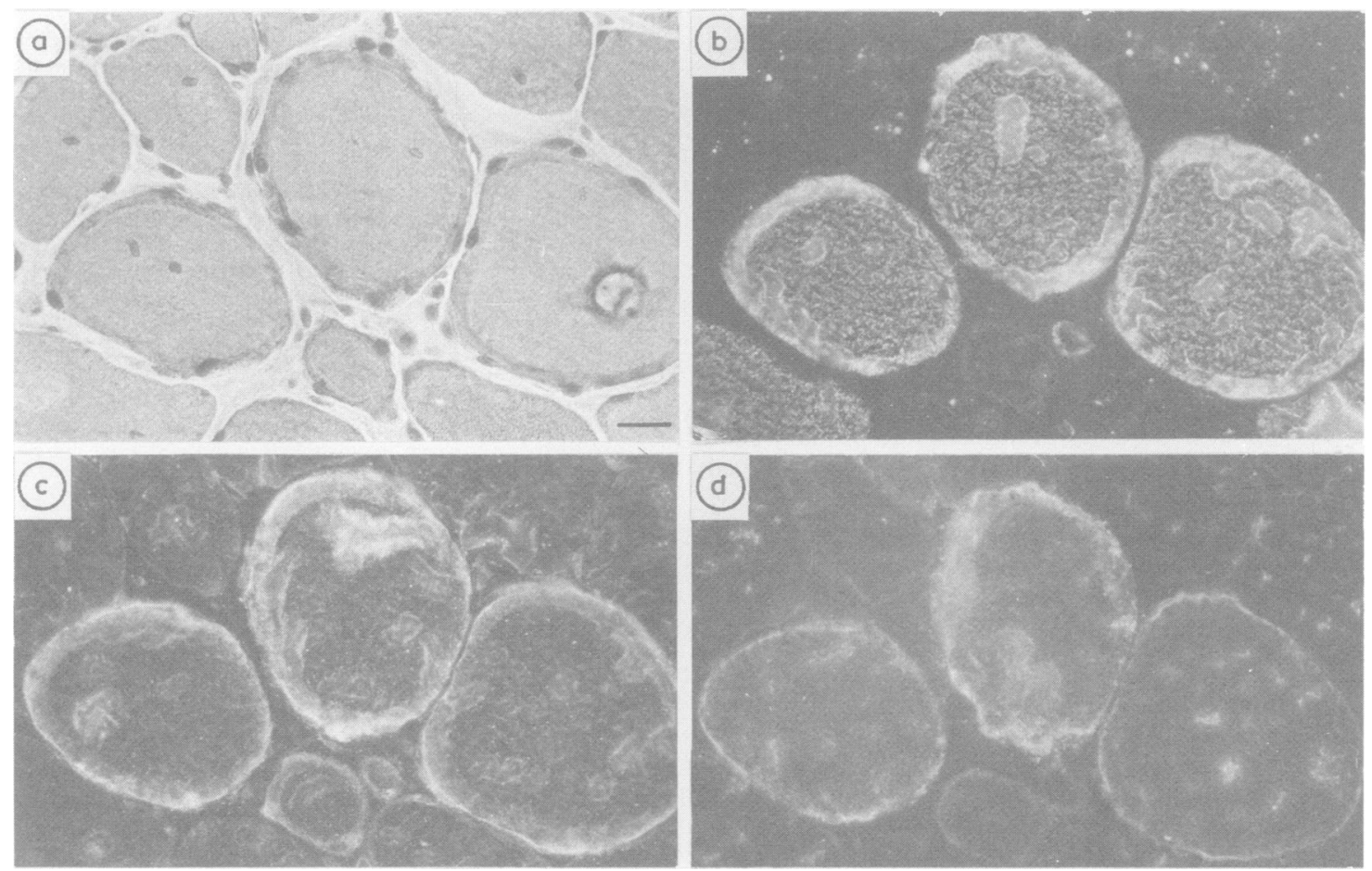

Fig Indirect immunofluorescence staining of serial sections of a muscle biopsy specimen from a myotonic dystrophy patient. (a) $H$ and E stain, (b) McAb 29.1D12 stain to show fast and slow myofibres, (c) anti-N-CAM stain and (d) McAb $5.1 H 11$ stain. Bar represents $100 \mu \mathrm{m}$.

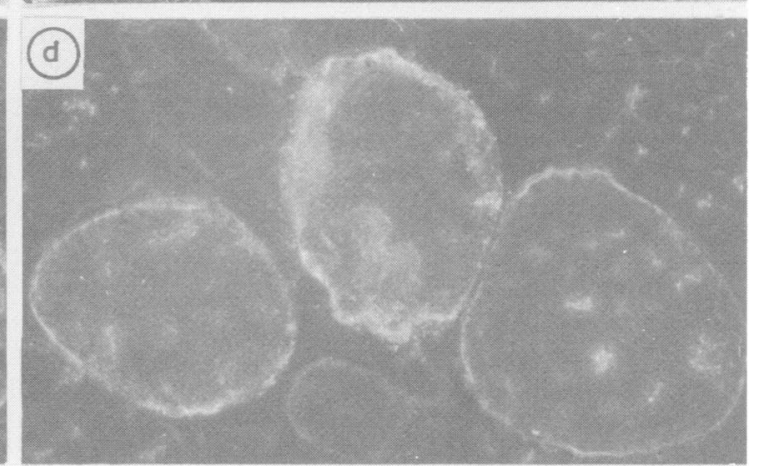

may represent staining of the T-tubules. ${ }^{10}$ The type 1 fibres were also stained by $\mathrm{N}-\mathrm{CAM}$ and $5 \cdot 1 \mathrm{H} 11$ antibodies and although these fibres were generally weaker in intensity, they were nevertheless all above background levels. All of the myotonic dystrophy specimens analysed in the present study reacted with $\mathrm{N}-\mathrm{CAM}$ and $5 \cdot 1 \mathrm{H} 11$ antibodies in a qualitatively similar manner and data on one case only are therefore presented. The reactivities reported above can therefore be regarded as common features of myotonic dystrophy muscle membranes. The indirect immunofluorescence analysis presented here allows an assessment as to whether or not an antigen is present in the muscle membrane but does not allow any conclusions regarding absolute levels of specific membrane antigens. Further quantitative analyses would be required to further address this point.

\section{Discussion}

The present data on the expression of N-CAM and $5 \cdot 1 \mathrm{H} 11$ in myotonic dystrophy biopsies taken together with our previous observations on their lack of expression in adult denervating disease ${ }^{1819}$ show that these two molecules and the apamin receptor are 
subject to similar control mechanisms in these samples of normal and diseased muscle. The so-called all or none expression of the apamin receptor is a feature that is not unique to this molecule but is shared by other nerve regulated gene products such as $\mathbf{N}-\mathrm{CAM}$ and $5 \cdot 1 \mathrm{H} 11$. One interesting aspect of the expression of these three muscle markers is that in myotonic dystrophy this occurs in innervated myofibres, both the hypertrophic type 2 fibres and the type 1 fibres, suggesting that there must be additional factors other than innervation status that can modulate their expression. For N-CAM this is the first evidence of factors other than innervation being able to control its expression in adult myofibres that normally repress the N-CAM gene. Recently we have shown that hormonal status can markedly effect expression of the N-CAM gene; experimentally induced hypothyroidism causes an activation of N-CAM gene expression in fully innervated myofibres. ${ }^{20}$ The expectation from animal denervation experiments is that N-CAM and apamin receptor would be present in muscle membranes of adults with denervating disease. However, none of the markers studied have been found to be expressed in these diseases. ${ }^{51518}$ Possible reasons for this apparent discrepancy include the suggestion that they occur below the detection level of the assays used or alternatively that adult denervating diseases are not indeed exact parallels of the animal experimental models. ${ }^{1921}$ Support for the latter proposal comes from one study of infantile muscular atrophy samples where denervated fibres express both $\mathrm{N}-\mathrm{CAM}$ and $5 \cdot 1 \mathrm{H} 11 .{ }^{19} 21$

The reported specificity found for apamin receptor expression between myotonic dystrophy and anterior horn cell disease is thus not unique since it is shared by at least two other membrane proteins N-CAM and $5 \cdot 1 \mathrm{H} 11$. It is therefore likely that the precocious expression of these gene products in myotonic dystrophy muscle reflects secondary changes occurring as a consequence of an as yet unidentified primary gene defect. While at least some of the electrophysiological features of myotonic dystrophy may be explained by increased or activated apamin receptor expression, the observed high levels of N-CAM and $5 \cdot 1 \mathrm{H} 11$ suggests that there is likely to be a number of secondary changes occurring in myotonic dystrophy muscle unlinked to the primary lesion, but perhaps mechanistically associated with the clinical phenotype. It will be of some interest to determine whether other muscle diseases, such as Duchenne muscular dystrophy, that express high levels of $\mathrm{N}-\mathrm{CAM}^{18}$ and $5 \cdot 1 \mathrm{H} 11^{15}$ also express apamin receptors.

This work was supported by the Muscular Dystrophy Group of Great Britain. We thank Dr J MorganHughes for clinical samples and Dr E Bock for the anti-D2-CAM antibody.

\section{References}

1 Harper PS. Myotonic Dystrophy. Philadelphia: Saunders, 1979.

2 Davies KE, Jackson J, Williamson R, et al. Linkage analysis of myotonic dystrophy and sequences on chromosome 19 using a cloned complement 3 gene probe. J Med Genet 1983;20:259-63.

3 O'Brien T, Ball S, Sarfarazi M, Harper PS, Robson EB. Genetic linkage between the loci for myotonic dystrophy and peptidase D. Ann Hum Genet 1983;47:117-21.

4 Appel SH, Merickel M, Gray R, Moore RB. Membrane abnormalities in the myotonic disorders. In: Serratrice G, Cros D, Desnuelle C, Gastaut JL, Pellissier JF, Pauget J, Schiano A, eds. Neuromuscular Diseases. New York: Raven Press, 1984:167-72.

5 Renaud JF, Desnuelle C, Schmid-Antomarchi H, Hugues M, Serratrice G, Lazdunski M. Expression of apamin receptor in muscles of patients with myotonic muscular dystrophy. Nature 1986;319:678-70.

6 Schmid-Antomarchi H, Renaud JF, Romey G, Hugues M, Schmid A, Lazdunski $M$. The all-or-none role of innervation in expression of apamin receptor and of apamin-sensitive $\mathrm{Ca}^{++}$-activated $\mathrm{K}^{+}$channel in mammalian skeletal muscle. Proc Natl Acad Sci USA 1985;82:2188-91.

7 Hugues M, Schmid H, Romey G, Duval D, Frelin C, Lazdunski $\mathrm{M}$. The $\mathrm{Ca}^{++}$dependent slow $\mathrm{K}^{+}$conductance in cultured rat muscle cells: characterization with apamin. EMBO $J$ 1982;1:1039-42.

8 Romey G, Lazdunski M. The coexistence in rat muscle cells of two distinct classes of $\mathrm{Ca}^{++}$-dependent $\mathrm{K}^{+}$channels with different pharmacological properties and different physiological functions. Biochem Biophys Res Commun 1984;118:669-74.

9 Moore SE, Walsh FS. Specific regulation of N-CAM/D2-CAM cell adhesion molecule during skeletal muscle development. EMBO J 1985;4:623-30.

10 Covault J, Sanes JR. Distribution of N-CAM in synaptic and extra-synaptic portions of developing and adult skeletal muscle. J Cell Biol 1986;102:716-30.

11 Moore SE, Walsh FS. Nerve dependent regulation of N-CAM expression in skeletal muscle. Neurosci 1986;18:499-505.

12 Covault J, Sanes JR. Neural cell adhesion molecule (N-CAM) accumulates in denervated and paralysed skeletal muscles. Proc Natl Acad Sci USA 1985;82;4544-8.

13 Rieger F, Grumet M, Edelman GM. N-CAM at the vertebrate neuromuscular junction. J Cell Biol 1985;101:285-92.

14 Walsh FS, Ritter MA. Surface antigen differentiation during human myogenesis in culture. Nature 1981;289:60-4.

15 Hurko O, Walsh FS. Human fetal muscle specific antigen is restricted to regenerating myofibres in diseased adult muscle. Neurology 1983;33:737-43.

16 Ibsen S, Berezin V, Norgaard-Pederson B, Bock E. Enzymelinked immunosorbent assay of the D2-glycoprotein. J Neurochem 1983;41:356-62.

17 Moore SE, Hurko O, Walsh FS. Immunocytochemical analysis of fibre type differentiation in developing skeletal muscle. $J$ Neuroimmunol 1984;7:137-49.

18 Walsh FS, Moore SE. Expression of cell adhesion molecule, N-CAM, in diseases of adult human skeletal muscle. Neurosci Lett 1985;59:73-8.

19 Walsh FS, Moore SE. Expression of muscle cell surface antigen $5.1 \mathrm{H} 11$ in infantile or juvenile spinal muscular atrophy. Neurology 1986;36:1140-2.

20 Thompson J, Moore SE, Walsh FS. Thyroid hormones regulate expression of the neural cell adhesion molecule (N-CAM) in adult skeletal muscle. FEBS Lett 1987;219:135-8.

21 Walsh FS, Moore SE, Lake BD. Cell adhesion molecule in N-CAM is expressed by denervated myofibres from WerdnigHoffmann and Kugelberg-Welander type spinal muscular atrophies. J Neurol Neurosurg Psychiatry 1987;50:439-42. 